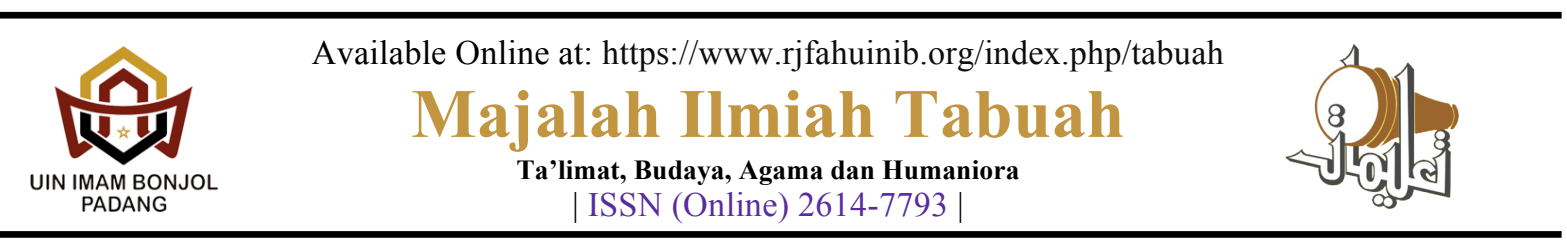

\title{
POLA PERLAWANAN KAUM ADAT DAN ULAMA DI KERINCI DALAM MENGHADAPI KOLONIALISME BELANDA
}

\author{
Jamal Mirdad \\ IAIN Batusangkar \\ email: jamalmirdad@iainbatusangkar.ac.id \\ Mami Nofrianti \\ IAIN Batusangkar \\ email: maminofrianti@iainbatusangkar.ac.id
}

\begin{abstract}
The people of Kerinci, before the arrival of the Dutch, had two patterns of leadership, namely Kaum Adat and Ulama. They had a significant role in drawing up and implementing existing regulations. The arrival of the Dutch colonialism to Kerinci upset the structure and instilled disorder within the community, so Kaum Adat and Ulama instigated anti-colonial movements in various forms and patterns. The research method used in this paper is library research with a descriptive analysis approach. The paper finds that the opposition of Kaum Adat was led by Depati Parbo. They adopted the guerilla warfare method. They also built fortresses in various places within the Kerinci region assisted by other Depati. Intensive communication between Depati was crucial in forming defence. Meanwhile, the resistance of the Ulama was led by H. Ismael in Pulau

Tengah. The Ulama also justified their resistance using religious parlances, and by making the Keramat mosque as the centre of the movement. Contrary to Kaum Adat, the Ulama fought openly against the Dutch by erecting fortifications at various points in Pulau Tengah.
\end{abstract}

Keywords: Resistance Patterns, Kaum Adat, Ulama, Kerinci

\section{Abstrak}

Masyarakat Kerinci sebelum kedatangan Belanda mempunyai dua pola kepmimpinan yaitu kaum adat dan ulama, mereka mempunyai peran signitifikan di tengah masyarakat Kerinci dalam menyusun serta menerapkan peraturan-peraturan yang ada.

Kedatangan Kolonialisme ke Kerinci dianggap merusak struktur dan tatanan masyarakat, sehingga kaum adat dan ulama melakukan pergerakan anti penjajahan dengan berbagai bentuk dan pola perlawanan.Metode yang digunakan dalam tulisan ini adalah metode kepustakaan (library research) dengan pendekatan deskriptif analisis, dengan temuan bahwaperlawanan kaum adat dipimpin oleh Depati Parbo dengan strategibergerilya dan membangun benteng di berbagai tempat di wilayah 
kerinci dengan dibantu oleh depati yang lainnya. Komunikasi yang intens antar Depati dilakukan oleh kaum adat dalam membentuk pertahanan. Sedangkanperlawanan ulama dipimpin oleh H. Ismael di Pulau Tengah, perlawanan kaum ulama menggunakan justifikasi agama dengan menjadikan masjid Keramat sebagai poros utama dan pusat pergerakan perlawanan terhadap Belanda, strategi yang digunakan adalah perang secara terbuka dengan mendirikan benteng di berbagai titik di Pulau Tengah.

Kata kunci: Pola Perlawanan, kaum adat, ulama, Kerinci

\section{PENDAHULUAN}

Kehadiran Kolonialisme di Indonesia berawal dari Perjanjian London antara Inggris dan Belanda, Inggris harus menyerahkan wilayah Indonesia kepada pihak Belanda sebagai tukaran daerah Malaka dan Ceylon. Pada tanggal 22 Mei 1819 secara resmi berkuasanya pihak Belanda atas wilayah pantai barat Sumatera. Langkah pertama yang dilakukan oleh Belanda adalah merealisasikan kekuasaan politiknya. Di sebagian wilayah Nusantara saat itu terjadi konflik-konflik internal yang terjadi dikalangan elite pribumi. Konflik ini dimanfaatkan oleh pihak Belanda untuk mencapai tujuannya. Dalam kondisi tersebut, tidak sedikit kelompok yang bersengketa meminta bantuan kepada pemerintahan Belanda. Pihak Belanda merespon keinginan dari elite tertentu kemudian menjadikan kelompok tersebut di bawah struktur pemerintahan Belanda. ${ }^{1}$

\section{Dampak}

Kehadiran

Kolonialisme menyebabkan perubahan global dalam semua bidang seperti: sistem politik, ekonomi, sosial dan budaya. Hal ini dapat dibuktikan dengan penguasaan kolonial terhadap sistem pelayaran dan perdagangan, bahkan mereka menetap diwilayah yang dapat menguntungkan persekutuannya, terutama di wilyah yang menjadi pusat komoditi rempah-rempah dan pusat pemerintahan.Selama pemerintahan

${ }^{1}$ Gusti Asnan. 2007. Dunia Maritim Pantai Barat Sumatera. Jogjakarta: Ombak. H. 70 kolonial berlangsung, secara perlahan dapat mempengaruhi budaya tradisional, serta ikut campur dalam struktural pemerintahan ditengah masyarakat, tenaga kerja diatur oleh sistem koloni dan pendidikan agama diawasi secara ketat, sehingga segala bentuk upaya yang dapat mengancam pemerintahan kolonial mereka hapuskan. ${ }^{2}$ Kolonialisme Belanda mulai menelusuri wilayah-wlayah pedalaman Sumatera untuk mencari rempahrempah dan bahan pokok yang lainnya, tidak terkecuali wilayah Kerinci. Pada tahun $1900 \mathrm{M}$, wilayah-wilayah pesisir pantai sumatera yang berbatas dengan wilayah Kerinci telah diambil alih oleh orang Belanda seperti Tapan, Pesisir Selatan Sumatera Barat, dan Mukomuko. Informasi tentang wilayah Kerinci mereka peroleh dari masyarakat Mukomuko dan Tapan, hal ini beralasan dikarenakan wilayah Tapan, Mukomuko dan Kerinci telah menjalinkan hubungan perdagangan jauh sebelum kedatangan Belanda.

Sebelum kedatangan

Kolonialisme ke Kerinci, masyarakat Kerinci memiliki dua bentuk pola kepemimpinan ditengah masyarakat yaitu kaum adat dan ulama.Disatu sisi kaum adat ini berperan sebagai orangorang yang memimpin pemerintahan, kemudian disisi lain ulama sebagai pemimpin spritual yaitu membimbing dan mengajarkan masyarakat tentang

${ }^{2}$ Naniek Harkantinigsih. 2014. Pengaruh Kolonial di Nusantara. KALPATARU, Majalah Arkeologi Vol. 23, No. 1., h. 77 
nilai-nilai keagamaan. Dua pola kepemimpinan itu berkembang selaras dan saling menghormati terhadap pola kehidupan sesama mereka. Kemudian dua pola ini diperkuat dengan adanya perjanjian Traktat Marapalam yang melahirkan simbol "adat bersandi Syara', Syara' bersandi Kitabullah" pengaruh Traktat Marapalam sampai ke wilayah-wilayah disekitar Sumatera termasuk wilayah Kerinci.

Kedatangan Kolonialisme ke Kerinci menimbulkan reaksi bagi kaum adat dan ulama serta masyarakat Kerinci umumnya. Bagi kaum adat, kedatangan Belanda akan merubah struktur pemerintahan di tengah masyarakat sehingga ada ketakutan di monopoli oleh pihak asing dalam kehidupan beradat. Sedangkan bagi pihak ulama, kedatangan Belanda tidak hanya membawa perubahan dari struktural pemerintahan namun mereka juga mengembangkan misi misionaris yaitu penyebaran agama Kristen. Dengan alasan itulah, baik kaum adat maupun ulama menentang kehadiran Kolonialisme di Kerinci. Untuk itu, dalam tulisan ini akan membahas tentang bentuk perlawanan kaum adat dan ulama serta hubungan antara dua pola perlawanan tersebut

\section{METODE PENELITIAN}

Metode penelitian yang digunakan adalahlibrary research (studi kepustakaan) dengan pendekatan deskriptif analisis,dengan menggunakan sumber sekunder berupa buku-buku, jurnal, yang membahas tentang perlawanan masyarakat Kerinci terhadap Kolonial Belanda. Sumbersumber tersebut ditelaah secara mendalam untuk melihat bentuk atau pola perlawanan kaum adat dan ulama serta hubungan dua perlawanan tersebut. Dalam kajian ini, perlawanan kaum adat lebih difokuskan terhadap perlawanan Depati Parbo serta jaringan yang dibangunnya, sedangkan perlawanan kaum ulama lebih difokuskan terhadap perlawanan $\mathrm{H}$.
Ismael di Pulau Tengah dengan santri sebagai basis pertama.Kemudian Dalam tulisan ini juga tidak banyak membicarakan peristiwa terjadi peperangan secara langsung, tetapi lebih terpokus kepada strategi pengumpulan masa atau pasukan, serta strategi yang diterapkan oleh Kaum Adat (Depati Parbo) dan ulama (H. Ismael) dalam melakukan perlawanan terhadap Belanda.

\section{PEMBAHASAN}

\section{Kaum Adat dan Ulamadi Kerinci}

Dalam kehidupan masyarakat pada umumnya dipimpin oleh kepalakepala rakyat yang disamakan sebagai pemimpin yang membentuk dan menjalankan aturan di tengah masyarakat. Hal ini selaras dengan apa yang dikatakan oleh Soerojo Wignjodiporo yang menyatakan di tengah-tengah masyarakat ada beberapa kepala rakyat yang fungsinya sama dengan pemimpin, ia berfungsi untuk memelihara jalannya hukum sebagaimana mestinya. ${ }^{3}$

Seperti halnya di masyarakat Kerinci terdapat pemimpim (kaum adat) yang mengatur dan menjalankan aturan di tengah masyarakat. Sistem kepemimpinan berbentuk federasi yang dipimpin oleh seorang yang bergelar depati. Pembentukan depati merupakan kelanjutan sistem sebelumnya yaitu masa kerajaan Sagindo yang juga menggunakan sistem federasi, artinya setiap depati menguasai daerah masingmasing tanpa ada campur tangan dari pihak lain.Kepemimpinan di Kerinci dikenal dengan istilah Depati EmpatDelapan Helai Kain, keempat orang penguasa itu sepakat dengan Depati Atur Bumi sebagai pimpinan yang dituakan (tertinggi).Adapun keempat depati tersebut adalah Depato Muro Langkap di Temiai, Depati Rencong Telang di Pulau Sangkar, Depati Biang Sari di Pengasi dan Depati

\footnotetext{
${ }^{3}$ Soerojo Wignjodiporo. 1990.Pengantar dan Asas-Asas Hukum Adat, Jakarta: PT. Toko Gunung Agung, h. 91
} 
Atur Bumi di Hiang. ${ }^{4}$ Selain Depati Empat Delapan Helai Kain, muncul juga beberapa depati yang menggunakan sistem otonomi sendiri, seperti: Lolo, Jujun, Pulau Tengah, Kumun, Sungai Penuh, Tanjung Pauh dan lain sebagainya. Jadi bentuk pemerintah pada saat itu adalah Demokrasi mufakat dengan sistemnya adalah; Balai Musyawarah Rendah dan Balai Musyawarah Tinggi.

Depatiberperan sebagai pimpinan yang paling tinggi di tengah masyarakat Kerinci, segala perkara yang datang kepadanya akan diadili di rumah adat dan keputusannya berada pada tangan depati. Depati itu memegang hukum dengan undangundang, membujur lalu melintang patah. Lantak tidak boleh goyah, cermin tidak boleh kabur, dicabut tidak mati, digeser tidak layu. Dengan kata lain, suatu perkara yang terjadi ditangah masyarakat diputuskan oleh depati, keputusannya tersebut melalui berbagai pertimbangan baik dari orang tua, cerdik pandai maupun ulama. ${ }^{5}$ Segala peraturan yang dikeluarkan dan segala hukuman yang dijatuhkan hendaklah menurut garis adat yang telah ditentukan yaitu adat bersandi sayara', syara' bersandi Kitabullah.

Disisi lain, ulama ikut serta mendampingi kaum adat dalam mengambil kebijakan dan keputusan, karena pepatah mengatakan syara' mengato, adat mumakai, ini murupakan implementasi falsafah adat bersandi sayara', syara' bersandi Kitabullah. Dengan adanya falsafah ini memberikan posisi penting ulama di tengah masyarakat Kerinci. Sehingga segala keputusan yang diambil oleh kaum adat harus terlebih dahulu meminta pertimbangan dari kaum ulama, sebab ulama orang yang tahu tentang seluk beluk agama Islam dan seluk beluk

\footnotetext{
${ }^{4}$ Rasyid Yakin. 1986.Menggali Adat Lama Pusaka Usang di Alam Sakti Kerinci, Sungai Penuh: CV Andalas,h. 11

${ }^{5}$ Eka Putra. (tt). Adat Budaya Kerinci, Sungai Penuh: ADZKI Printing, h. 39
}

tentang surau dan masjid. Dalam setiap musyawarah negeri, ulama tidak bisa ditinggalkan karena mereka mengetahui norma-norma agama sehingga mereka menentukan suatu aturan yang tidak bertentangan dengan agama Islam.

Peran ulama di dalam masyarakat Kerinci adalah sebagai pemimpin umat dan simbol pemersatu, ia menjadi panutan dan tempat menyelesaikan permasalahanpermasalahan yang berkaitan dengan persoalan agama di tengah masyarakat.Keberadaan ulama di tengah masyarakat kerinci tidak hanya sebatas persoalan agama yang menyangkut ibadah dan mahdhah saja, tetapi mencakup seluruh aspek kehidupan sehari-hari. Kehadiran ulama juga dijadikan guru dalam pendidikan, tak heran jika ulama dimuliakan oleh santri dan masyarakat yang ada di Kerinci.

Semenjak abad ke-17 dan 18, di dusun Pulau Tengah telah menjadi suatu komunitas dan pusat pendidikan yang dibimbing oleh ulama, dimana ulama dan masjid sebagai poros utama dalam segala kegiatan. Dusun Pulau Tengah kedatangan para santri yang berasal dari berbagai penjuru daerah Kerinci dan diluar wilayah Kerinci seperti Sungai Manau, Serampas-Suangai Tenang, Muara panco, Muara Bungo, NgaolTabir Ulu, dan dari daerah Minangkabau (Pesisir Selatan). Pada abad ke 19 hingga abad ke 20 Pulau Tengah juga telah melahirkan banyak tokoh tokoh ulama terkemuka di alam Kerinci seperti H.Ismail, H.Saleh dan H.Rauf, disamping ulama ulama tersebut Pulau Tengah juga memiliki ulama ulama kharismatik seperti H.Ahmad Fakir. H.Abdul Muti, H.Abdul Aziz, H. Saud, H. Leman, H.Abdul Rahman. H.Ahmad, dan H.Mukhtar.Para ulama ulama terkemuka di Pulau Tengah sebagian besar mendalami ilmu agama di tanah suci Makkah dan di negeri tetangga Kedah-Malaya. Para ulama terkemuka tersebut masing masing memiliki pusat 
pengajian dan dakwah di surau surau yang ada di dusun pulau tengah. ${ }^{6}$

\section{Perlawanan Kaum adat dan Ulama terhadap Kolonialisme Perlawanan Kaum Adat}

Kerinci sebelum kedatangan Belanda telah menjalin kerjasama dengan wilayah sekitarnya yaitu wilayah Indrapura (Minangkabau) dan Jambi. Perjanjian ini dikenal dengan "Persumpahan di Bukit Setinjau Laut Lunang", persumpahan ini diikrarkan oleh Pangeran Temenggung dari Jambi, Depati Empat Delapan Helai Kain, Pegawai Rejo Pegawai Jenang, Suluh Bindang Alam Kerinci dari kerinci, dan Tuanku Hitan Berdarah Putih dari Kerajaan Indrapura, membahas kerjasama antara Kerinci, Indrapura dan Jambi untuk saling membantu dalam hal ekonomi dan pertahanan maupun dalam bidang yang lainnya. Hal ini dapat dibuktikan dengan ditemukannya naskah bertuliskan Arab Melayu dibuat pada tanggal 23 Ramadhan 1246 H. ${ }^{7}$ Kerjasama antara Indrapura dan Kerinci membawa dampak positif khususnya dalam bidang ekonomi dan pertahanan. Dalam bidang ekonomi masyarakat Kerinci dengan masyarakat Indrapura dan sekitarnya telah melakukan transaksijual beli. Kerinci yang dikenal dengan hasil bumi seperti kopi, beras di bawa ke daerah Tapan dan Indrapura, kemudian mereka membawa pulang barang bahan pakaian, garam dan barang lainnya yang diperlukan oleh masyarakat Kerinci. ${ }^{8}$ kerjasama ini terus berlanjut

\footnotetext{
6 Budhi Vrihaspathi Jauhari, "Perkembangan Islam di Kerinci", dalam https://kerincitime.co.id/perkembangan-islamdi-alam-kerinci.html, diakses tanggal 24 September 2019

7 Dasiba, dkk, Sejarah Perjuangan Rakyat kerinci Mempertahankan Kemerdekaan Republik Indonesia 1945-1949). Dinas Pariwisata dan Kebudayaan Pemerintah Kabupaten Kerinci. 2004, h. 14

${ }^{8}$ Tim Peneliti. 1972. Depati Parbo. Sungai Penuh: Pemerintah Daerah Kerinci, h. 16
}

sampai kedatangan pihak Kolonialisme di Indrapura dan kerinci.

Awal abad ke-20 Kolonialisme sudah menguasaiwilayah Mokomuko, Pesisir Selatan, dan Sumatera Barat pada umumnya, sehingga orang Belanda mulai melirik wilayah-wilayah pedalaman di antaranya wilayah Kerinci sebab pihak kolonial tidak merasa puas dengan hanya menguasai wilayahwilayah pesisir pantai saja, namun mereka juga berambisi menguasai wilayah-wilayah pedalaman seperti wilayah Kerinci, karena wilayah ini merupakan penghasil beras dan kopi dengan kualitas tinggi, dengan tanah yang subur membuat tiap-tiap masyarakat menanam padi dan kopi sehingga dapat menghasilkan devisa bagi pemerintah. ${ }^{9}$

Kedatangan kolonialisme di Kerinci direspon oleh seluruh kalangan seperti kaum adat, ulama, santri serta masyarakat untuk melakukan pergerakan dan perlawanan terhadap kolonialisme Belanda. Setiap kasus pergerakan dan perlawanan sangat erat dengan kemunculan pemimpim, Michael Adas memberikan istilah "pemimpin kenabian", istilah ini didefinisikan sebagai seorang yang percaya dan mampu meyakinkan orang lain bahwa ia mempunyai kontak khusus dengan kekuatan supranatural. Para pengikutnya mempercayai bahwa sosok pemimpim tersebut memiliki kekuatan yang melebihi manusia biasa, yang sering ditunjukkan dalam kemampuan meramal, bertarung dan menyembuhkan. ${ }^{10}$

Dalam proses pemberontakan, setidaknya ada tiga faktor yang mendorong terjadinya perlawanan untuk

9 A. Ph. van Aken. 1915.Catatn Mengenai Afdeling Kurinci, dalam Biro Ensiklopaedi, Laporan Biro untuk Urusan Pemerintahan Dari Daerah Sebarang Lautan, Terbitan VIII, h. 16

${ }^{10}$ Michael Adas, (pent) M. Tohir Effendi. 1998. Ratu Adil "Tokoh dan Gerakan Milinarian Menentang Kolonialisme Eropa". Jakarta: Rajawali, h. XVI 
menghilangkan dominasi kekuatan asing yaitu:

1. Keputusan para pemimpin dalam mengajak dan memimpin masyarakat atau pengikutnya untuk melaksanakan pemberontakan.

2. Ketakutan akan hilangnya kekuasaan atau struktur yang sudah ada akan beralih dan mengalami perubahan.

3. Gagalnya para penguasa kolonial untuk mengambil tindakan cepat dalam mengatasi para pemberontak. 11

Perang Kerinci berlangsung antara 1902 dan 1903, meskipun perang ini terjadi dalam waktu singgkat, tetapi itu sudah cukup untuk memunculkan kecemasan yang meluas, bahkan getarannya mencapai Batavia. ${ }^{12}$ Pertempuran pertama antara masyarakat Kerinci dengan kolonialisme terjadi di Ranah Menjuto, Belanda mulai menelusuri wilayah Ranah Manjutodan mendirikan pertahanan dan pos untuk bisa melakukan invansi ke wilayah Kerinci. Pengiriman pasukan ke Kerinci dilatarbelakangi oleh terbunuhnya utusan dari Belanda yang bermarkas di Mukomuko yaitu Imam Marusa dan Imam Mahdi, mereka diminta untuk menyampaikan pesan kepada pemimpin rakyat Kerinci supaya tidak melakukan perlawanan, karena misi mereka ke Kerinci adalah membuat jalan dari Padang ke Jambi, peristiwa ini menjadi pemicu peperangan di Ranah Manjuto.Keberadaan Pasukan Belanda di Ranah Manjuto diketahui oleh kaum adat dan tokoh masyarakat yang ada di desa Lolo dan Lempur, untuk menghentikan pasukan Belanda tersebut pemimpin kaum adat yaitu Depati Parbo mempersiapkan hulubalang untuk menyerang pos dan pertahanan Belanda

\footnotetext{
${ }^{11}$ Ibid, h. 217

${ }^{12}$ M. Dien Madjid dan Johan Wahyudi. 2018. Local Resistence in Kerinci in the $20^{\text {th }}$ Century: Depati Parbo and the People's Struggle Against the Power of the Dutch East Indies (A Study of Archives and Oral History). TAWARIKH: International Journal for Historical Studies. Volume 9, No. 2.
}

di Ranah Manjuto. Dengan strategi bergerilya, dan pengetahuan geografis (kondisi alam) yang tidak asing bagi Depati Parbo dan pasukan, sehingga mereka berhasil memukul mundur pasukan Belanda yang jumlahnya jauh lebih banyak dibandingkan pasukan dari Depati Parbo. ${ }^{13}$

Penyergapan bersifat gerilya yang dilakukan oleh Depati Parbo tersebut dipandang ampuh karena mendapat dukungan dari pasukannya dan penguasaan medan perang, serta lokasi musuh. Dengan perpaduan gerakan yang dinamis dan terselubung ditambah dengan kondisi alam yang bergununggunung dan berlembah curam dapat membuat pasukan Belanda kocar kocir dan kehilangan arah.Strategi bergirlya ini sangat cocok diterapkan di daerah Indonesia pada umumnya, karena kondisi alam sangat mendukung untuk menerapkannya. Strategi bergerilya sangat efektif, mereka dapat mengelabui, menipu atau bahkan melakukan serangan kilat. Taktik ini juga sangat membantu menyerang musuh dengan jumlah besar yang kehilangan arah dan tidak menguasai medan. Kadang taktik ini juga mengarah pada taktik mengepung secara tidak terlihat. Strategi bergerilya ini dapat diterapkan di wilayah-wilayah yang mempunyai kondisi alam berhutan lebat, bergunung-gunung, berlembah curam ataupun yang memiliki rintangan alam yang lainnya. ${ }^{14}$

Kemenangan Depati Parbo di Ranah Manjuto sangat penting bagi para pejuang yang ada Di Kerinci, kemengan ini akan membentuk perlawanan lainnya di berbagai daerah. Ia dijadikan sebagai inspirasi oleh para depati dan hulubalang untuk bergabung dan ikut

${ }^{13}$ Budhi VrihaspathiJauhari dan Eka Putra. 2012.Senarai Sejarah Kebudayaan Suku Kerinci, Sungai Penuh: Bina Potensia Aditya Mahatya Yodha Kota Sungai Penuh dan Kabupaten Kerinci Provinsi Jambi, h. 130-131

${ }^{14}$ A.H. Nasution, Pokok-pokok Gerilya: dan Pertahanan Republik Indonesia di Masa lalu dan yang Akan Datang, Bandung: Angkasa 1984, h. 41 
serta dalam menghadapi

kolonialisme.Kondisi ini sebenarnya sudah lama diprediksi oleh para Depati di Kerinci, cepat atau lambat peperangan ini akan mendatangi mereka, sehingga mereka sudah lama mempersiapkan diri dengan melakukan serangkaian simulasi aksi perang, bila memungkinkan akan menerapkan perang raya yakni dengan menggerakkan potensi rakyat dalam mnghadapi penindasan. Depati Parbo juga menyambangi daerah-daerah dan melakukan pertemuan untuk menentukan strategi dalam menghadapi Belanda. ${ }^{15}$

Semenjak penyerangan utusan Belanda di Kerinci dan penyergapan yang terjadi di Ranah Manjuto, para pimpinan tiap-tiap dusun (Depati) melakukan musyawarah di Rawang ${ }^{16}$ yang terdiri dari para Depati masingmasing. Musyawarah ini dipimpin oleh Depati Empat Delapan Helai Kain, Agenda pertemuan pada saat itu yaitu menentukan sikap kepada Belanda. Padapertemuan tersebut kemudian diputuslah di Sanggarang Agung, yaitu "Kalau Belanda masuk Kerinci melalui arah Timur, sama-sama kita ke Timur, kalau datang dari arah Barat saman-

15 Johan Wahyudi. 2017.Perlawanan Depati Parbo di Mata Kolonialisme Belanda di Kerinci: Suatu Kajian Sejarah Lokal. Tamaddun, Volume. 5, No. 1, h. 13

16 Rawang merupakan suatu daerah kekuasaan Atur Bumi "Depati Empat Delapan Helai Kain", daerah ini merupakan pusat musyawarah adat alam kerinci, Hamparan Besar Tanah Rawang adalah tempat tempat bermusyawarah/sidang Pleno para depati sealam Kerinci serta tempat membicarakan berbagai masalah yang personil yang menyangkut seluruh rakyat Kerinci. Hal ini menggambarkan perlambang adanya satu kesatuan masyarakat Kerinci. Selaian di Rawang juga terdapat Sandaran Agung yaitu tempat kedua musyawarah Alam Kerinci, jikalau di Rawang tidak menghasilkan keputusan, maka sidang selanjutnya di bawa ke daerah Sandaran Agung. Lihat Budhi Vrihaspathi Jauhari dan Suhatman Jaya. 2012.Kerinci Menyimpan Peninggalan Pusaka. Sungai Penuh: Bina Potensia Aditya Mahatya Yodha Kota Sungai Penuh dan Kabupaten Kerinci Provinsi Jambi, h. 30 sama ke Barat, kalau sudah di tengah, sama-sama di kepung". ${ }^{17}$ Keputusan pertemuan tersebut, memberikan intruksi kepada depati untuk bekerjasama dengan depati yang lainnya serta memerintahkan para hulubalang dan masyarakat untuk membangun benteng di berbagai titik, supaya menghambat pasukan Belanda serta menyerangmereka dengan kekuatan penuh. Pembangunan benteng serta penyergapan berhasil dilakukan di beberapa titik seperti di Koto Limau Sering, Hiang, Lolo, Lempur dan Pulau Tengah, meskipun tempat-tempat yang dimaksud adalah tempat-tempat basis terbesar dalam peperangan, namun masih banyak lagi benteng yang dibangun oleh kaum adat di Kerinci yang dipolopori oleh para Depati setiap daerah. Hal ini juga diungkapkan oleh Wahyudi sebagaimanadalam catatan kolonial, perang terjadi hampir serentak, dan memakan waktu lama. Medan perang yang menyajikan duel seru ini terjadi di; Hiyang (12 Juni 1903), Batu Hampar (14 Juni - 10 Juli), Kerinci Utara (15-16 Juni 1903), Sangaran Agung (17 Juni 1903), Jujun dan Pidung (17 Juni -21 Juni 1903), Tanjung Batu (18 Juni 1903), Koto Lanang (19 Juni 1903), Sungai Penuh (21 Juni 1903), Tanjung Pauh (1 Juli 1903), Bukit Kemanten (1 Juli 1903), Pengasi (3 Juli 1903), Benteng Koto Tuwa (4 Juli 1903), Pulau Sangkar (717 Juli 1903), Rawang (8 Juli 1903), Sungai Pusaka (12-13 Juli 1903), Lempur (17 - 22 Juli 1903), Lolo (1419 Juli 1903), Lempur Semurup (21 Juli 1903), Benteng Batu Putih (27 Juli 1903), Benteng Bukit (19 Juli 1903) serta tidak menutup kemungkinan di daerah-daerah lainnya. ${ }^{18}$

Setiap benteng yang dibangun dijaga oleh beberapa hulubalang dari setiap daerah.Misalkan perlawanan di Koto Limau Sering diperkuat oleh

\footnotetext{
${ }^{17}$ Iskandar Zakaria. 1985. "Tambo Sakti Alam Kerinci III”. (Tidak Diterbutkan), h. 9192

${ }^{18}$ Wahyudi, op. cit, h. 13-14
} 
hulubalang berasal dari Belui, Semurup, Siulak, Sungai Penuh, Pondok Tinggi dan Rawang dengan memaksa pasukan Belanda mundur ke Indrapura. Pertempuran di Talang Tahantak (Siulak) dibantu oleh hulubalang dan deapati dari Balui, Semurup, Kemantan, Sikungkung, Koto Lanang dan sekitarnya yang dipimpin langsung oleh Depati Parbo. ${ }^{19}$ Kaum adat (para depati)berperan penting dalam mengorganisir masyarakat untuk mengadakan perlawanan.Keberhasilan kaum adat (depati) mengorganisir perlawanan terhadap kolonial Belanda tidak terlepas dari status mereka sebagai pemimpin di tengah masyarakat, mereka sebagai pemegang dan pelaksana hukum, sehingga mereka sangat dihormati, dan segala keputusannya akan dilaksanakan.Selain dari itu, interaksi antara depati satu daerah dengan depati yang lainnya selalu menjalin hubungan dan komunikasi dengan baik, hal ini dapat membentuk benteng yang sangat kuat. Hal ini dapat dibuktikan dengan komunikasi intens antara Depati Parbo dengan depati yang lainnya dalam hal mengompa semangat juang para kaum adat yang ada di Kerinci.

\section{Perlawanan ulama}

Beberapa perlawanan di Indonesia lebih banyak menggunakan justifikasi agama dibandingkan dengan yang lainnya, hal ini seperti yang diungkapkan oleh Muhammad Iskandar bahwa kehadiran kolonial pada mulanya dianggap sebagai gangguan budaya, terutama karena perbedaan agama. Orang Belanda yang dianggap kafir dan disertai dengan berbagai konotasi negatif lainnya seperti kikir, licik dan mudah ingkar janji. Oleh karena itu, ideologi untuk melakukan perlawanan terhadap pemerintah kolonial adalah dengan melancarkan jihad atau perang suci. Banyak peperangan dan perlawanan yang dilatarbelakangi oleh ideologi jihad fisabilillah seperti:

\footnotetext{
${ }^{19}$ Tim Peneliti, op. cit, h. 24-25
}

Perang di Aceh, perlawanan Sultan Diponogoro, perlawanan Syekh Yusuf al Makassari, perlawanan Sultan Thaha Saifuddin Jambi, dan perlawanan lainnya yang dapat dijadikan contoh terjadinya sekralisasi perang melawan Belanda berdasarkan justifikasi agama. $^{20}$

Dalam beberapa catatan sejarah perjuangan masyarakat Kerinci melawan Belanda, perlawanan masyarakat Pulau Tengah menjadi perlawanan yang sengit dan terbesar, perlawanan ini dipimpin oleh ulama dan didukung oleh kaum adat, santri serta masyarakat setempat. Seperti yang telah digambarkan bahwa dusun Pulau Tengah menghimpun santri dari berbagai penjuru Kerinci dan dari luar Kerinci, sehingga mereka inilah yang paling bergairah dalam melawan Belanda, sebab ideologi yang mereka gunakan adalah ideologi jihadfisabilillahdan media yang mereka gunakan adalah surau atau masjid sebagai pusat perlawanan.

Dalam konteks perlawanan yang ada di Pulau Tengah dibangun dengan dasar sentimen, perasaan, dan keterikatan, dalam rangka membawa massa yang banyak diperlukan sosok kepemimpinan yang bersifat komunal dan patuh. Gerakan perlawanan dapat dilihat pada penggunaan simbol tertentu secara massal, yang dimotivasi oleh sentimen dan perasaan keterikatan dan kemudian posisi pemimpin menjadi pusat sentral dari gerakan yang dilancarkan. ${ }^{21}$ Maka dari itu majulah seorang ulama yang memimpin gerakan tersebut,seorang ulama termashur, yaitu Haji Ismael.

Sikap ketakutan Belanda terhadap gerakan keagamaan sudah lama, gerakan ini dipandang sebagai gerakan

${ }^{20}$ Mohammad Iskandar dan Achmad Fauzia, Islam dan Kolonialisme, dalam Ensiklopedia Tematis Dunia Islam Asiatenggara. Jakarta: PT. Ichtiar Baru Van Hoeve, h. 322

21 Umi Sumbulah. 2006.Agama, Kekerasan dan Perlawanan Ideologis. Islamica Jurnal Studi Keislaman", voll, nomor 1, h. 2 
potensial yang berbahaya, dan mesti dihadapi dengan penuh kewaspadaan. Belanda yakin bahwa gerakan keagamaan bisa dipergunakan oleh pemimpin-pemimpin Islam sebagai basis kekuatan untuk memberontak. ${ }^{22}$

Seperti halnya gerakan keagamaan yang ada di Pulau Tengah, masyarakat hidupdilingkungan masjid yang penuh dengan ketaatan nilai-nilai Islam, sehingga jama'ah Masjid Keramat merupakan komunitas tersendiri di mana ulama, pengurus, santri dan masyarakat hidup dalam satu lingkungan, mereka seperti keluarga besar di bawah asuhan para ulama. Dalam tataran ini, Masjid Keramat Pulau Tengah yang dipimpin oleh ulama dijadikan pusat perlawanan dalam peperangan melawan Belanda. Hal ini diperkuat dari surat langsung dari Snouck Hurgronje Kepada Gubernur N-I "....Masyarakat Kerinci tidak bisa berperang, mereka hanya para petani yang takut pengaruh kita, namun mereka telah dihasut oleh beberapa orang ulama yang fanatik, bagi orangorang Islam fanatik mesti kita usir dan lenyapkan",23

Ulama dan masyarakat Kerinci telah mempersiapkan strategi yang matang dalam merespon kedatangan Belanda, seperti benteng dan senjatasenjata yang digunakan, meskipun senjata tersebut masih tradisional yaitu berupa keris, tombak, pedang dan lainlain. Untuk mensukseskan penyergapan yang dilakukan, maka tokoh dan wadah yang digunakan juga ikut berperan dalam pencapaian misi tersebut. Wadah yang digunakan dalam perjuangan masyarakat Kerinci yaitu Masjid

${ }^{22}$ Martin van Bruinessen. 1992. Tarekat Naqsabandiyah di Indonesia. (Bandung: Mizan, h. 27-28

${ }^{23}$ Surat langsung dari Snouck Hurgronje Kepada Gubernur N-I. Dipetik dari Ambtelijke Advieger Van C. Snouck Hurgronje 1889-1936, Uitgegaven Door E. Gobes er C. Adriaanse, Jilid III 's Gravenhage 1965. Diterjemahkan oleh: Mr. Concrad Williyam Watson dari Universitas Kebangsaan Malaysia, 30 April 1975
Keramat Pulau Tengah, yang dijadikan pusat perjuangan atau pergerakan dalam menentang Belanda.Dalam merespon kedatangan Belanda, $H$. Ismael menghimpun kekuatan di Pulau Tengah, ia mengajak santri, kaum adat dan masyarakat untuk mempersiapkan diri untuk melawan kemungkaran dan kekafiran, ada beberapa tahap atau langkah yang dilakukan oleh ulama beserta masyarakat dalam menghadapi pasukan Belanda, yaitu:

a. Tahap Musyawarah

Musyawarah di lakukan di depan halaman Masjid Keramat, seluruh lapisan masyarakat seperti ulama, kaum adat, tokoh masyarakat, para santri, dan masyarakat pada umumnya. Hasil dari musyawarah tersebut adalah menolak untuk bekerjasama dan dikendalikan oleh penjajah (orang kafir), serta menentang secara langsung pihak Belanda dengan cara mengundang mereka untuk datang ke Pulau Tengah.

b. Tahap Pembekalan Spritual

Salah satu persiapan yang dilakukan oleh ulama dalam melanjutkan misi perlawanan adalah memberikan semangat juang kepada santri beserta dengan masyarakat umum lainnya dengan cara menceritakan untaian kisah Nabi Muhammad SAW dalam menghadapi orang-orang yang ingkar dalam perang Badar, Uhud, dan Khandaq.

c. Tahap Sumpah Setia.

Masyarakat melakukansumpah setia yaitu"Kami masyarakat Pulau Tengah menolak untuk bekerjasama dan dikendalikan oleh sikafir, kami ikhlas untuk bertempur melawan orang kafir sampai pada titik darah penghabisan dan sekali-sekali tidak mau tunduk kepada mereka, biar mati bergelimang darah dan seandainya kalah sanggup menjadi gajah dan harimau di hutan". 
Kemudian mereka lanjutkan dengan meminum "air Alqur'an"24.

d. Membangun Benteng

Masyarakat beserta dengan ulamamembuat benteng di beberapa tempat yaitu Lubuk Pagar, Sungai Buai, Dusun Baru, Talago, Tanjung Putih dan Masjid Keramat sebagai benteng utama dalam mengorganisir semua benteng dan pertahanan di Pulau Tengah ${ }^{25}$.

Perlawanan ulama yang berbasis di Masjid dan surau ini, merupakan perlawanan secara terbuka dalam menentang kolonialisme Belanda, dengan cara mengundang pihak Belanda untuk menuju ke Pulau Tengah. Menurut Scott, salah satu perlawanan yang dilakukan oleh masyarakat adalah perlawanan secara terbuka. Perlawanan ini dilakukan dalam bentuk kekerasan atau perlawanan secara terorganisir, sistematis dan berprinsip atau tidak mementingkan diri sendiri sehingga mereka mempunyai tujuan untuk menghilangkan atau mencegah dominasi suatu kekuasaan terhadap wilayah mereka. ${ }^{26}$ Penyergapan dan perlawanan yang dilakukan oleh masyarakat di Pulau Tengah, memicu kemarahan pasukan Belanda sehingga mereka membakar dusun Baru Pulau Tengah dan menguasai wilayah Kerinci secara utuh.

\section{KESIMPULAN}

Perlawanan yang dilakukan oleh masyarakat Kerinci pada umumnya didasari atas kebencian mereka terhadap orang Belanda yang berbeda agama, kebudayaan, serta memiliki sifat-sifat licik, kikir dan mudah ingkar janji. Perlawanan ini didukung oleh sosok pemimpin yang mereka ikuti dalam kehidupan sehari-hari baik itu dari kaum adat maupun dari kalangan ulama.

Perlawanan yang terjadi di Kerinci dapat dikelompokkan menjadi dua yaitu pertama perlawanan yang dipimpin oleh kaum adat dan kedua perlawanan yang dipimpin oleh ulama. Perlawanan kaum adat bersifat menyeluruh dan membangun komunikasi antara depati setiap daerah, mereka membangun benteng-benteng diberbagai titik dan dijaga hulubalang dari berbagai daerah. Kaum adat yang diwakili oleh Depati Parbo juga menggunakan strategi bergerilya dalam menghadapi pasukan Belanda. Sedangkan perlawanan yang dipimpin oleh ulama memanfaatkan daerah Pulau Tengah sebagai basis pendidikan, perlawanan lebih kental mengatas namakan agama, sehingga masjid dijadikan pusat pergerakan dan perlawanan terhadap Belanda, para ulama mengundang pasukan Belanda dalam perang terbuka dan mempersiapkan benteng-benteng untuk menahan serangan dari pasukan Belanda.
${ }^{24}$ Meminum “air al-Qur'an” adalah sebuah ritual dalam melakukan sumpah setia, didalam sebuah piduk (perahu nelayan) di masukkan air berserta al-Qur'an di dalamnya. “Air al-Qur'an" bertujuan untuk menambah semangat dan meminta pertolongan dari Allah SWT. Jamal Mirdad. 2019. Masjid Sebagai Pusat Perlawanan Terhadap Kolonialisme Belanda (Studi Kasus: Masjid Keramat Pulau Tengah Kerinci). Tsaqofah \& Tarikh: Jurnal Kebudayaan dan Sejarah Islam. Volume 4. No. 1.

${ }^{25}$ Ibid.

${ }^{26}$ James C. Scoot, moral Ekonomi Petani, Pergolakan dan Subsistensi di Asia Tenggara, jakarta: LP3ES, 1981, h. 69 


\section{DAFTAR KEPUSTAKAAN}

Adas, Michael, (pent) M. Tohir Effendi. 1998. Ratu Adil "Tokoh dan Gerakan Milinarian Menentang Kolonialisme Eropa”. Jakarta: Rajawali.

Aken, A. Ph. van. 1915.Catatn Mengenai Afdeling Kurinci, dalam Biro Ensiklopaedi, Laporan Biro untuk Urusan Pemerintahan Dari Daerah Sebarang Lautan, Terbitan VIII.

Ambtelijke Advieger Van C. Snouck Hurgronje 1889-1936, Uitgegaven Door E. Gobes er C. Adriaanse, Jilid III 's Gravenhage 1965. Diterjemahkan oleh: Mr. Concrad Williyam Watson dari Universitas Kebangsaan Malaysia, 30 April 1975

Asnan, Gusti. 2007. Dunia Maritim Pantai Barat Sumatera. Jogjakarta: Ombak.

Dasiba, dkk. Sejarah Perjuangan Rakyat kerinci Mempertahankan Kemerdekaan Republik Indonesia 1945-1949). Dinas Pariwisata dan Kebudayaan Pemerintah Kabupaten Kerinci. 2004.

Harkantinigsih, Naniek. 2014. Pengaruh Kolonial di Nusantara. KALPATARU, Majalah Arkeologi Vol. 23, No. 1.

Iskandar, Mohammad dan Achmad Fauzia, Islam dan Kolonialisme, dalam Ensiklopedia Tematis Dunia Islam Asiatenggara. Jakarta: PT. Ichtiar Baru Van Hoeve.

Jauhari, Budhi Vrihaspathi. "Perkembangan Islam di Kerinci", dalam

https://kerincitime.co.id/perkemba ngan-islam-di-alam-kerinci.html, diakses tanggal 24 September 2019.

Jauhari, Budhi Vrihaspathi dan Eka Putra. 2012.Senarai Sejarah
Kebudayaan Suku Kerinci, Sungai Penuh: Bina Potensia Aditya Mahatya Yodha Kota Sungai Penuh dan Kabupaten Kerinci Provinsi Jambi.

Jauhari, Budhi Vrihaspathi dan Suhatman Jaya. 2012. Kerinci Menyimpan Peninggalan Pusaka. Sungai Penuh: Bina Potensia Aditya Mahatya Yodha Kota Sungai Penuh dan Kabupaten Kerinci Provinsi Jambi.

Madjid, M. Dien dan Johan Wahyudi. 2018. Local Resistence in Kerinci in the $20^{\text {th }}$ Century: Depati Parbo and the People's Struggle Against the Power of the Dutch East Indies (A Study of Archives and Oral History). TAWARIKH: International Journal for Historical Studies. Volume 9, No. 2.

Mirdad, Jamal. 2019. Masjid Sebagai Pusat Perlawanan Terhadap Kolonialisme Belanda (Studi Kasus: Masjid Keramat Pulau Tengah Kerinci). Tsaqofah \& Tarikh: Jurnal Kebudayaan dan Sejarah Islam. Volume 4. No. 1.

Nasution, A.H. 1984. Pokok-pokok Gerilya: dan Pertahanan Republik Indonesia di Masa lalu dan yang Akan Datang, Bandung: Angkasa.

Putra, Eka. (tt). Adat Budaya Kerinci, Sungai Penuh: ADZKI Printing.

Scoot, James C. 1981. Moral Ekonomi Petani, Pergolakan dan Subsistensi di Asia Tenggara, Jakarta: LP3ES

Sumbulah, Umi. 2006. Agama, Kekerasan dan Perlawanan Ideologis. Islamica Jurnal Studi Keislaman", voll, nomor 1.

Tim Peneliti. 1972. Depati Parbo. Sungai Penuh: Pemerintah Daerah Kerinci. 
Van Bruinessen, Martin. 1992. Tarekat Naqsabandiyah di Indonesia. Bandung: Mizan.

Wahyudi, Johan. 2017. Perlawanan Depati Parbo di Mata Kolonialisme Belanda di Kerinci: Suatu Kajian Sejarah Lokal. Tamaddun, Volume. 5, No. 1.

Wignjodiporo, Soerojo. 1990.Pengantar dan Asas-Asas Hukum Adat, Jakarta: PT. Toko Gunung Agung.

Yakin, Rasyid. 1986.Menggali Adat Lama Pusaka Usang di Alam Sakti Kerinci, Sungai Penuh: CV Andalas.

Zakaria, Iskandar. 1985. "Tambo Sakti Alam Kerinci III". (Tidak Diterbutkan). 